\title{
Comparison of Neuroendocrine Responses in Open and Laparoscopic Appendectomies in Children: A Randomized Controlled Trial
}

\section{Çocuklarda Apendektomide Gelișen Nöroendokrin Yanıtın Açık ve Laparoskopik Yöntemlerde Karșilaștıııması: Randomize Kontrollü Çalıșma}

\author{
Aysel Erdem Salkaya1, Özgür Özbağrıaçık2, Alp Akay3, Sibel Oba4, Serkan Arslan5 \\ ${ }^{1}$ Kağıthane State Hospital, Clinic of Anesthesiolog and Reanimation, Istanbul, Turkey \\ 2Dünya Göz Hospital, Clinic of Anesthesiology and Reanimation, Istanbul, Turkey \\ 3Şişli Memorial Hospital, Clinic of Anesthesiolog and Reanimation, Istanbul, Turkey \\ ${ }^{4}$ Şişli Etfal Training and Research Hospital, Clinic of Anesthesiology and Reanimation, Istanbul, Turkey \\ 5Dicle University Faculty of Medicine, Department of Pediatric Surgery, Diyarbakır, Turkey
}

\section{ABSTRACT}

Aim: To compare the neuroendocrine changes and responses to surgical stress in open and laparoscopic appendectomy techniques in children.

Materials and Methods: Sixty-seven patients aged between six and 14 years presented to the pediatric surgery clinic between July and September 2008 with acute abdominal pain and were enrolled into this study. Patients had class I-II disease, according to the American Society of Anesthesiology, and were scheduled for open and laparoscopic appendectomies. The patients were randomly divided into two groups according to the method of appendectomy used. The neuroendocrine responses of both groups were then compared. Results: No statistical difference was observed between the open and laparoscopic appendectomy groups in terms of age, gender, weight, or duration of surgery ( $p>0.05)$. In addition, no statistical difference was observed between the mean arterial pressure (MAP), cardiac apex beat (CAB), peripheral oxygen saturation $\left(\mathrm{SpO}_{2}\right)$, and end tidal carbon dioxide pressure $\left(\mathrm{ETCO}_{2}\right)$ values of the open and laparoscopic appendectomy groups at 0, 5, 10, 15, 30, 60 minutes, and at the end of the operation ( $p>0.05$ ). There was no statistical difference between the mean values of $\mathrm{MAP}, \mathrm{CAB}, \mathrm{SpO}_{2}$, or $\mathrm{ETCO}_{2}$ of the groups at the end of the operation and at $1,2,3,12$, and 24 hours postoperatively $(p>0.05)$ or between the mean glucose, prolactin, or cortisol levels of the two groups at 0 and 30 minutes and at the end of the operation ( $p>0.05$ ).

Conclusions: This study demonstrated that neuroendocrine responses to surgical stress were similar in open and laparoscopic appendectomy operations in children. No significant difference was found between the responses developed in either group.

Keywords: Appendectomy, children, laparoscopy, neuroendocrine
ÖZ

Amaç: Bu çalışmamızda çocuklarda açık ve laparoskopik apendektomi tekniklerinin cerrahi strese yanııın ve oluşan nöro-endokrin değişikliklerin karşısaştırı Iması amaçlandı.

Gereç ve Yöntemler: Temmuz ve Eylül 2008 tarihleri arasında çocuk cerrahisi kliniğine başvuran akut karın ağrısı olgularında açık ve kapalı laparoskopik apendektomi planlanan Amerikan Anesteziyoloji Derneği I-II, altı-14 yaş arası 67 olgu rastgele 2 grup oluşturularak her iki grubun nöro-endokrin yanıtı karşılaştıııııı̧̧ır.

Bulgular: Açık apendektomi ve laparoskopik apendektomi gruplarının yaş ortalamaları, cinsiyet dağılımları, kilo ortalamaları, operasyon süresi ortalamaları arasında istatistiksel farklılı gözlenmemiştir $(p>0,05)$. Açık apendektomi ve laparoskopik apendektomi gruplarının 0., 5., 10., 15., $30 ., 60$. dakika ve operasyon sonu ortalama arter basınc (OAB), kalp tepe atımı (KTA), periferik oksijen satürasyonu $\left(\mathrm{SPO}_{2}\right)$, endtidal karbon dioksit basincı $\left(\mathrm{ETCO}_{2}\right)$ ortalamaları arasında istatistiksel farklılık gözlenmemiştir $(p>0,05)$. Ayrıca her iki grubun Post 0 p., 1., 2., 4., 12., 24. saat $\mathrm{OAB}, \mathrm{KTA}, \mathrm{SPO}_{2}$, $\mathrm{ETCO}_{2}$ ortalamaları arasında istatistiksel farkılık gözlenmemiş̧ir $(p>0,05)$. Açık apendektomi ve laparoskopik apendektomi gruplarının 0. ve 30. dakika operasyon sonu glikoz, prolaktin, kortizol ortalamaları arasında istatistiksel farklılık gözlenmemiştir $(p>0,05)$.

Sonuç: Çalışmamızda çocuklarda açık ve laparoskopik apendektomilerde cerrahi strese karşı gelişen nöro-endokrin yanıtın benzer olduğu gösterilmiştir. Her iki grupta gelişen nöro-endokrin yanıt arasında bir fark tespit edilmemiştir. Anahtar Kelimeler: Apendektomi, çocuklar, laparoskopi, nöro-endokrin 


\section{Introduction}

Several endocrine, metabolic, and immunologic changes occur during the stress response to trauma and surgery. The hormones released as a result of such stimulation are controlled by the hypothalamo-hypophyseal and autonomic nervous system. This axis plays a role in endocrine regulation during the response to surgery and includes several signal and feedback effects (1). Currently, laparoscopic surgery is becoming increasingly popular. However, surgical trauma induces a neurohormonal response in the body, leading to catabolic effects such as reduced insulin susceptibility, decreased carbohydrate storage, increased blood glucose levels, and degradation of lipid and protein, along with the occurrence of sodium and water retention (2-4). The size of the incision is crucial in studies conducted to explore the neuroendocrine stress parameters created by surgery. These parameters are used to evaluate the neuroendocrine response in open and laparoscopic appendectomies and include insulin, cortisol, glucose, and prolactin levels $(5,6)$.

In this study, we aimed to compare the responses and neuroendocrine changes due to surgical stress in open and laparoscopic appendectomies in children.

\section{Materials and Methods}

This study was conducted in the operating rooms of the clinic of pediatric surgery between July 2008 and September 2008. Approval was received from the Ethics Committee of Şişli Etfal Training and Research Hospital.

Sixty-seven patients aged between 6 and 14 years with a physical status of class I-II, according to the classification system of the American Society of Anesthesiologists (ASA), presented to the pediatric surgery clinic with acute abdominal pain. These patients were scheduled for open or laparoscopic appendectomy and were randomly divided into two groups without considering the physical examination or laboratory findings. The laparoscopic method was preferred for daytime operations due to technical issues. Patients with a systemic infection, endocrine disease, metabolic disease, or suspected perforation, as well as those who had difficulty cooperating, were excluded from the study.

All patients were initially physically examined, and the laboratory findings were then evaluated. The visual analog scale-a scoring system used to determine the severity of pain was explained to the patients and their families. Patients were asked to numerically express their pain status as 0 in the case of no pain and 10 for the most severe pain. Patients were also informed about the availability of patient-controlled analgesia (PCA) for postoperative pain control. Informed consent forms were received from all patients prior to the start of this study.

Vascular access was obtained before surgery and blood samples were collected for prolactin, cortisol, and glucose analysis at 0, 30, and 60 minutes and also at the end of the operation. Chemiluminescence was performed with a clinical immunoassay analyzer (E170; Roche Diagnostics, Basel, Switzerland) to analyze the level of cortisol and prolactin. The level of glucose was determined by photometry using the Architect C16000 clinical chemistry analyzer (Abbott Diagnostics, Lake Forest, IL, USA).

Initiation of general anesthesia was achieved with $1 \mu \mathrm{g} /$ $\mathrm{kg}$ of intravenous fentanyl, $5-7 \mathrm{mg} / \mathrm{kg}$ thiopental, and $0.5 \mathrm{mg} /$ $\mathrm{kg}$ atracurium. Orotracheal intubation was also obtained. Anesthesia was maintained with 50\% oxygenise $+50 \%$ nitrous oxide $+1.5 \%$ sevoflurane.

Statistical analyses were performed with the NCSS 2007 statistical software package (NCSS LLC, East Kaysville, UT, USA). Descriptive statistical methods (mean and standard deviation) were used to evaluate the data, and analyses of variance tests were performed in repeated measures of the groups. The Newman-Keuls multiple comparison test was used to compare the subgroups, while an independent t-test was used in the comparison of the two groups. A chi-squared test was performed to compare qualitative data. The level of statistical significance was set at $p<0.05$.

\section{Results}

The demographic features of the patients are shown in Table I. No statistical difference was observed between the open and laparoscopic appendectomy groups in terms of age, gender, weight, or duration of surgery $(p>0.05)$. In terms of the mean end tidal carbon dioxide pressure $\left(\mathrm{ETCO}_{2}\right)$ values, a significant difference was identified between the groups at 30 and 60 minutes and at the end of the operation $(p<0.05)$. However, the mean arterial pressure (MAP), cardiac apex beat $(\mathrm{CAB})$, and peripheral oxygen saturation $\left(\mathrm{SpO}_{2}\right)$ values were similar between the two groups at $0,5,10,15,30$, and

Table I. Demographic features of patients who have undergone open and laparoscopic surgery aandlaparoscopic laparoscopic appendectomy

\begin{tabular}{|c|c|c|c|c|c|}
\hline & & \multirow{2}{*}{$\begin{array}{l}\text { Group I } \\
\text { Open appendectomy }\end{array}$} & \multicolumn{3}{|l|}{ Group II } \\
\hline & & & Laparoskopic appendectomy & $t$ & $\mathrm{p}$ \\
\hline Age & & $8.96 \pm 3.06$ & $10.03 \pm 3.22$ & -1.38 & 0.173 \\
\hline \multirow{2}{*}{ Gender } & Male & $26(72.2 \%)$ & $21(67.7 \%)$ & \multirow{2}{*}{$\chi^{2}=0.16$} & \multirow{2}{*}{0.689} \\
\hline & Female & $10(27.8 \%)$ & $10(32.3 \%)$ & & \\
\hline Weight & & $29.61 \pm 11.34$ & $31.1 \pm 9.28$ & -0.58 & 0.567 \\
\hline Operation time & & $61.96 \pm 20.98$ & $71.12 \pm 28.06$ & -1.18 & 0.244 \\
\hline
\end{tabular}


60 minutes, and at the end of the operation. They were also similar at 1,12 , and 24 hours postoperatively ( $p>0.05$ ).

The mean levels of the neuroendocrine response parameters, including glucose, prolactin, and cortisol, were similar between the groups at 0,30 , and 60 minutes, and at the end of the operation ( $p>0.05$ ) (Table II). The histopathological diagnosis was as follows: acute appendicitis in 40 patients, perforated appendicitis in 12, and lymphoid hyperplasia in 8 .

\begin{tabular}{|c|c|c|c|c|c|}
\hline & & Group I & Group II & & \\
\hline & & Open appendectomy & Laparoscopic appendectomy & $t$ & $p$ \\
\hline \multirow{9}{*}{ MAP } & 0 . minute & $82.65 \pm 16.08$ & $82.57 \pm 14.88$ & 0.02 & 0.985 \\
\hline & 30. minute & $92.13 \pm 14.44$ & $90.7 \pm 11.46$ & 0.43 & 0.671 \\
\hline & 60. minute & $87.31 \pm 10.17$ & $88.27 \pm 12.68$ & -0.25 & 0.804 \\
\hline & End of operation & $90.91 \pm 14.17$ & $92.38 \pm 14.83$ & -0.4 & 0.69 \\
\hline & \multicolumn{5}{|l|}{ Postoperative } \\
\hline & 1. hour & $86.68 \pm 12.31$ & $84.47 \pm 11.63$ & 1.69 & 0.095 \\
\hline & 4. hour & $84.96 \pm 10.48$ & $84.68 \pm 10.99$ & 1.04 & 0.306 \\
\hline & 12. hour & $84.35 \pm 8.95$ & $83.6 \pm 8.68$ & 0.96 & 0.343 \\
\hline & 24. hour & $85.86 \pm 9.48$ & $83.89 \pm 9.48$ & 0.62 & 0.544 \\
\hline \multirow{8}{*}{ CAB } & 0. minute & $110.91 \pm 29.24$ & $124.86 \pm 163.39$ & -1.19 & 0.238 \\
\hline & 30. minute & $111.59 \pm 28.3$ & $106.97 \pm 17.32$ & 0.79 & 0.436 \\
\hline & 60. minute & $116.94 \pm 26.54$ & $108.32 \pm 16.91$ & 1.25 & 0.22 \\
\hline & End of operation & $115.06 \pm 23.58$ & $109.79 \pm 16.51$ & 1.02 & 0.313 \\
\hline & Postoperative & $111.4 \pm 16.37$ & $104 \pm 18.96$ & 1.7 & 0.094 \\
\hline & 1. hour & $106.56 \pm 19.28$ & $103.58 \pm 18.26$ & 0.64 & 0.526 \\
\hline & 12. hour & $101.22 \pm 12.41$ & $98.39 \pm 8.48$ & 1.58 & 0.121 \\
\hline & 24. hour & $99.8 \pm 12.59$ & $99.3 \pm 14.64$ & 0.08 & 0.936 \\
\hline \multirow{8}{*}{$\mathrm{SPO}_{2}$} & 0 . minute & $99.53 \pm 0.56$ & $99.77 \pm 0.43$ & -1.91 & 0.06 \\
\hline & 30. minute & $99.26 \pm 1.58$ & $99.68 \pm 0.54$ & -1.38 & 0.173 \\
\hline & 60. minute & $99.61 \pm 0.5$ & $99.77 \pm 0.43$ & -1.1 & 0.279 \\
\hline & End of operation & $99.53 \pm 0.56$ & $99.77 \pm 0.43$ & -1.91 & 0.06 \\
\hline & Postoperative & $99.62 \pm 0.60$ & $99.65 \pm 0.71$ & -0.17 & 0.866 \\
\hline & 1. hour & $99.42 \pm 0.92$ & $99.52 \pm 0.77$ & -0.45 & 0.655 \\
\hline & 12. hour & $99.45 \pm 0.69$ & $99.40 \pm 0.6$ & 0.25 & 0.807 \\
\hline & 24. hour & $99.70 \pm 0.48$ & $99.44 \pm 0.73$ & 0.91 & 0.374 \\
\hline \multirow{8}{*}{$\mathrm{ETCO}_{2}$} & 0. minute & $33 \pm 4.16$ & $34.67 \pm 3.2$ & -1.2 & 0.242 \\
\hline & 30. minute & $32.38 \pm 3.28$ & $36.83 \pm 3.93$ & -3.33 & 0.002 \\
\hline & 60. minute & $31.33 \pm 3.16$ & $36 \pm 5.31$ & -2.34 & 0.031 \\
\hline & End of operation & $31.93 \pm 1.9$ & $35.29 \pm 4.33$ & -2.7 & 0.012 \\
\hline & \multicolumn{5}{|l|}{ Glikoz } \\
\hline & 0. minute & $103.66 \pm 45.65$ & $88.61 \pm 10.6$ & 1.79 & 0.078 \\
\hline & 30. minute & $178.52 \pm 127.19$ & $132.14 \pm 51.56$ & 1.82 & 0.074 \\
\hline & End of operation & $198.56 \pm 145.74$ & $162.61 \pm 87.32$ & 1.19 & 0.238 \\
\hline \multirow{3}{*}{ Prolaktin } & 0. minute & $14.31 \pm 11.21$ & $25.49 \pm 43.26$ & -1.45 & 0.151 \\
\hline & 30. minute & $39.88 \pm 21.46$ & $49.89 \pm 22.27$ & -1.77 & 0.081 \\
\hline & End of operation & $34.34 \pm 16.59$ & $34.51 \pm 16.80$ & -0.04 & 0.967 \\
\hline \multirow{3}{*}{ Cortizol } & 0. minute & $25.58 \pm 9.87$ & $22.03 \pm 6.47$ & 1.7 & 0.095 \\
\hline & 30. minute & $28.56 \pm 10.11$ & $27.00 \pm 9.88$ & 0.6 & 0.552 \\
\hline & End of operation & $37.80 \pm 14.89$ & $37.93 \pm 7.93$ & -0.04 & 0.967 \\
\hline
\end{tabular}




\section{Discussion}

The prevalence of laparoscopic interventions has recently increased in both adults and children. The advantages of this method include decreased wound infections, a shorter postoperative recovery time, reduced time to return to normal activities, and a reduced need for postoperative analgesia (7-9). Open and laparoscopic appendicitis studies exist in the literature, but few have investigated the neuroendocrine response (10-12).

Surgical stress is a good indicator to use when evaluating the advantages of a new method and can be quantified by measuring hormones or cytokines in the blood. Studies have reported that the levels of blood glucose, adrenocorticotropic hormone, interleukin (IL)-1, cortisol, prolactin, antidiuretic hormone (ADH), growth hormone, and catecholamine increase due to the endocrine and metabolic response to surgical stress, while the levels of insulin and testosterone decrease $(13,14)$. In support of these findings, Burton et al. (4) demonstrated that the stress physiological response to surgical trauma leads to a change in the manner of hormone secretion, including cortisol and anabolic hormones; in that study, the plasma levels of cortisol were increased, but the level of insulin was suppressed (4). Bozkurt et al. (7) compared the systemic stress factors in 29 ASA class children (aged between 1.5 and 4 years) who had undergone laparoscopy or laparotomy (7); arterial blood gas, prolactin, cortisol, IL-6, glucose, insulin, lactic acid, and epinephrine levels were evaluated from the induction of anesthesia to the end of the operation. In addition, heart rate, mean arterial blood pressure, $\mathrm{ETCO}_{2}$, and oxygen saturation were also recorded during the operation (7). In our study, the increase in the mean level of $\mathrm{ETCO}_{2}$ may be related to the absorption of $\mathrm{CO}_{2}$ administered to the abdomen during laparoscopy.

In other studies, the increase in the levels of insulin, cortisol, prolactin, epinephrine, lactate, and blood glucose was insignificant between laparoscopy and an open operation). These studies showed that the level of surgical stress created by laparoscopy in pediatric patients did not differ from that resulting from laparotomy (15). The levels of IL-6 were increased in both groups, although the difference was not statistically significant. No difference was found between the hemodynamic values (heart rate and MAP) of either group (15). In a study conducted by Peters et al. (16) and Walder and Aitkenhead (17) in, the presence of a pneumoperitoneum led to the enhanced secretion of $\mathrm{ADH}$, adrenaline, noradrenaline, dopamine, rennin, and cortisol $(16,17)$. The stress parameters in our study were similar to these studies. Blood glucose, prolactin, and cortisol values were higher in both groups. However, there was no difference between the two groups. This finding suggests that both methods cause a similar level of stress.
Bozkurt et al. (7) evaluated the efficiency of analgesia and the neuroendocrine response in patients treated with epidural morphine and PCA; 44 children aged between 5 and 15 years and scheduled for lower abdominal surgery were included in their study and were divided into two groups after the induction of anesthesia. Group I was administered morphine $(0.1 \mathrm{mg} / \mathrm{kg})$ in saline $(0.2 \mathrm{~mL} / \mathrm{kg})$ via an epidural; Group II was administered morphine $(0.1 \mathrm{mg} /$ $\mathrm{kg}$ ) intravenous. The levels of glucose, insulin, cortisol, and morphine were then monitored at 1, 8, 12, and 24 hours after anesthesia. Heart rate, blood pressure, respiratory rate, Wong-Baker FACES pain scale score, sedation score, and complications were then compared between the two groups at 24 hours postoperatively. The increase in the level of cortisol, blood glucose, and insulin was similar in both groups, and respiratory depression was not observed. In our study, respiratory depression was not observed with the administration of PCA. Unlike the above study, we aimed to compare the effects of laparoscopic and open surgeries on the stress response; although the levels of cortisol, glucose, and insulin had increased, no significant difference was found between the groups.

\section{Conclusion}

This study demonstrated that the neuroendocrine response to surgical stress was similar in open and laparoscopic appendectomies performed on children. No significant difference was observed between the neuroendocrine responses developed in either group. However, $\mathrm{ETCO}_{2}$ was significantly different between the groups.

\section{Ethics}

Ethics Committee Approval: The article is in accordance with the Animal Ethics Committee for the Şişli Etfal Education and Research Hospital, (No: 07.07.2008, verdict: $60)$, This study was published as a working thesis in 2009, The English in this document has been checked by at least two professional editors, both native speakers of English. (Textcheck reference number: 16041810), Informed Consent: Consent form was filled out by all participants.

Peer-review: Externally peer-reviewed.

\section{Authorship Contributions}

Surgical and Medical Practices: Aysel Erdem Salkaya, Concept: Aysel Erdem Salkaya, Design: Aysel Erdem Salkaya, Data Collection or Processing: Aysel Erdem Salkaya, Özgür Özbağrıaçık, Alp Akay, Analysis or Interpretation: Aysel Erdem Salkaya, Alp Akay, Sibel Oba, Özgür Özbağrıaçık, Literature Search: Aysel Erdem Salkaya, Alp Akay, Sibel Oba, Writing: Aysel Erdem Salkaya, Serkan Arslan.

Conflict of Interest: No conflict of interest was declared by the authors.

Financial Disclosure: The authors declared that this study has received no financial support. 


\section{References}

1. Schwartz S. Principle Surgery. 7nd ed. RR Donelley Sons. 1999;3-53.

2. Avtan L, Berber E, Avcl C. Laparoskopik cerrahide postoperatif analjezi. Journal of Analjezia 1996;8:22-5.

3. Weissman $\mathrm{C}$. The metabolic response to stress: an overview and update. Anesthesiology. 1990;73:308-27.

4. Burton D, Nicholson G, Hall G. Endokrin and metabolic response to surgery. BJA-CEPD Revlews 2004;4:144-7.

5. Fasting S, Søreide E, Raeder JC. Changing preoperative fasting policies. Impact of a national consensus. Acta Anaesthesiol Scand 1998;42:1188-91.

6. Wallash B. Trauma. Shoemaker. WC. Textbook of critical care, 4nd ed. London: WB Saunders company; 1998;1230321.

7. Bozkurt P, Kaya G, Altintas F, et al. Systemic stress response during operations for acute abdominal pain performed via laparoscopy or laparotomy in children. Anaesthesia 2000;55:5-9.

8. Divarcı E, Kılıç F, Kangın M. A Comparison of Laparoscopic Versus Open Appendectomy for The Treatment of Acute Appendicitis in Children. IKSST Derg 2014;6:37-40.

9. Uysal M, Küçükaydın M, Çiftler AN, Arslan S, Aslan A. Complications After Open and Laparoscopic Appendectomy in Perforated Appendicitis of Children. Erciyes Medical Journal 2011;33:117-20.
10. Quezada F, Quezada N, Mejia R, et al. Laparoscopic versus open approach in the management of appendicitis complicated exclusively with peritonitis: a single center experience. Int J Surg 2015;13:80-3.

11. Xiao $Y$, Shi G, Zhang J, et al. Surgical site infection after laparoscopic and open appendectomy: a multicenter large consecutive cohort study. Surg Endosc 2015;29:1384-93.

12. Scirè G, Mariotto A, Peretti M. Laparoscopic versus open appendectomy in the management of acute appendicitis in children: a multicenter retrospective study. Minerva Pediatr 2014;66:281-5.

13. Wiesel S, Grillas R. Patient-controlled analgesia after laparoscopic and open cholecystectomy. Can J Anaesth 1995;42:37-40.

14. Oh TE. Endocrine disorders. In: Oh TE. Intensive care manuel. 4 nd edition. Oxfort: A Division of Reed Educational and Professional Publishing Ltd, 1997;565-614.

15. Lin E, Lowry SF, Calvano SE. The systemic responce to injury. In: Principles of surgery Schwartz SI, Shires GT, Daly JM, Ficher JE, Gallovay AC (eds), 7th ed. Mgraw- Hill New York, 1999;3-51.

16. Peters S, Paik, Robert W, Beard Jr. New and Controversial isues in the management of colorektal diseases, Lap Colectomy. Surg Clin North Am 1997;7.

17. Walder $A D$, Aitkenhead AR. Role of vasopressin in the haemodynamic response to laparoscopic cholecystectomy. $\mathrm{Br}$ J Anaesth 1997;78:264-6. 